\title{
Association between COVID-19 diagnosis and economic class, race/skin color and social distancing in Brazilian university students
}

\author{
Associação entre o diagnóstico de COVID-19 e a classe econômica, raça/cor \\ da pele e distanciamento social em universitários brasileiros
}

André Eduardo da Silva Júnior ${ }^{1}$ (D), Mateus de Lima Macena² (D), Isabele Rejane de Oliveira Maranhão Pureza $^{1}$ (D), Ana Debora Santos de Oliveira ${ }^{2}$ (D), Dafiny Rodrigues Silva Praxedes ${ }^{2}$ (D), Telma Maria de Menezes Toledo Florêncio² (D), Ana Paula Grotti Clemente² (D), Nassib Bezerra Bueno² (D)

\begin{abstract}
Purpose: To determine the association between diagnosis of COVID-19 and the economic class, race/skin color, and adherence to social distancing in Brazilian university students. Methods: This is a nationwide cross-sectional study carried out with online questionnaires applied to Brazilian university students, at 94 universities in the public and private education network. Self-reported age, sex, economic class data, race/skin color, COVID-19 diagnosis, and adherence to social distancing measures were collected. Results: 5,984 individuals were evaluated. No significant association was found between the diagnosis of COVID-19 and economic class and race/skin color in the multivariable analysis. However, we observed that there were significant associations between the diagnosis of COVID-19 and partial adherence to social distancing, with leaving home only for going to work (PR: $1.35 ; 95 \% \mathrm{CI}: 1.10-1.66$; $\mathrm{p}$ $<0.01$ ) and with non-adherence to social distancing (PR: 1.96; 95\% CI: 1.29-2.97; p <0.01). Conclusion: The diagnosis of COVID-19 was associated with age, non-adherence and partial adherence to social distancing measures in Brazilian university students, but was not associated with race/skin color and economic class.
\end{abstract}

Keywords: SARS-CoV-2, Economic status, Ethnic groups, Race factors.

\section{RESUMO}

Objetivo: Verificar a associação entre o diagnóstico de COVID-19 e a classe econômica, raça/cor da pele e adesão às medidas ao distanciamento social em universitários brasileiros. Métodos: Estudo transversal, de abrangência nacional, realizado com universitários brasileiros. Foram coletados dados autorreferidos de idade, sexo, classe econômica, raça/cor, diagnóstico do COVID-19 e adesão às medidas de distanciamento social. Resultados: 5.984 indivíduos foram avaliados. Não foi encontrada associação significativa entre o diagnóstico de COVID-19, a classe econômica e raça/cor na análise multivariável. Observamos que houve associações significativas entre o diagnóstico de COVID-19 e adesão parcial ao distanciamento social (RP: 1,35; IC 95\%: 1.10-1.66; p < 0,01) e com a não adesão ao distanciamento social (RP: 1,96; IC95\%: 1.29-2.97; $p<0,01$ ). Conclusão: O diagnóstico de COVID-19 foi associado à idade, não adesão e adesão parcial às medidas de distanciamento social em universitários brasileiros, mas não se associou à raça/cor e classe econômica.

Palavras-chave: SARS-CoV-2, Status econômico, Grupos étnicos, Fatores raciais.

1. Universidade Federal de São Paulo. Escola Paulista de Medicina. Programa de Pós-Graduação em Nutrição (SP), Brazil.

2. Universidade Federal de Alagoas. Faculdade de Nutrição. Programa de Pós-Graduação em Nutrição, (AL), Brazil. 


\section{INTRODUCTION}

The first cases of the disease caused by the infection with the new coronavirus (COVID-19) occurred in Wuhan, China, in December 2019. With the absence of assertive decisions to contain the contagion by this virus, COVID-19 spread around the world. On 30 January, the World Health Organization (WHO) declared the outbreak of COVID-19 as a Public Health Emergency of International Interest, which subsequently became a global pandemic ${ }^{1}$. After approximately two months of the reports in Wuhan, Brazil presented its first COVID-19 diagnosis on 26 February 2020². COVID-19 has nonspecific symptoms such as: fever, dry cough, headache, fatigue, diarrhea, anosmia, ageusia, and dyspnoea, and in some patients, it can progress to more severe cases leading to severe acute respiratory syndrome ${ }^{3,4}$.

Many measures around the world have been taken to reduce the transmission of the virus and, consequently, the number of deaths. These measures are based on the use of personal protective equipment, rapid identification of symptomatic patients by real-time polymerase chain reaction (RT$\mathrm{PCR}$ ) or rapid tests, isolation of patients with positive results, and identification of contacts close to patients to quarantine them ${ }^{5}$. As seen in other respiratory epidemics, public health measures such as social distancing can be decisive in controlling the spread of the disease. This consists of reducing interactions between people in a wider community, in which individuals isolate themselves even though they do not know whether they are infected or not by the virus $^{6}$. However, the Brazilian population has shown low adherence to the proposed recommendations of social distancing, which may be contributing to the high rates of infection and bed occupation in intensive care units nationwide ${ }^{5}$. Low adherence to social distancing is generally seen in low- and middleincome countries, with large populations living in overcrowded conditions, where social distancing and even access to clean water cannot be guaranteed ${ }^{7}$.

Due to the lack of effective treatments and mass vaccination of the population, some measures to encourage social distancing have been applied in the world to slow down the rate of transmission and deaths by COVID-19, such as the closure of educational institutions, since kindergarten to universities $^{8}$. In Brazil, the closure of universities across the country was adopted in early March 2020 and until the beginning of 2021 the resumption of face-to-face classes has not yet occurred completely. The sudden change in the students' routine generated unexpected demands, highlighting the need to adapt to work and remote study ${ }^{9}$. This type of sudden change in lifestyle can have harmful effects on students' mental and physical health and reproduce strong economic losses and low educational engagement ${ }^{10}$. Therefore, investigating the magnitude of the influence of socioeconomic conditions and adherence to social distancing in relation to infection can better understand the impact of social distancing measures, such as the closure of universities. Although the social determinants of health and their relationship with COVID-19 are being widely investigated in the general population, no other study, to our knowledge, has evaluated these issues in Brazilian university students. Thus, the present study aimed to determine the association between diagnosis of COVID-19 and the economic class, race/skin color, and adherence to social distancing in Brazilian university students.

\section{METHODS}

\section{Ethical aspects}

The research protocol was approved by the Research Ethics Committee of the Universidade Federal de Alagoas (process number: 4.410.403). All participants were presented with the consent form on the first page of the virtual questionnaire. It was necessary to accept it to access the questionnaire and start data collection.

\section{Study design, location, and sample}

This is a cross-sectional study and is a secondary analysis of the project entitled "Prevalence of food addiction in university students during the COVID-19 pandemic". This study was conducted with Brazilian university students enrolled in courses in any area of knowledge, at 94 universities in the public and private education network. Data collection occurred by completing an online questionnaire between 27 October and 11 December (between epidemiological weeks 44 and 50 of 2020). Brazil presented its first case and the first death of COVID-19 in the 10th and 12th epidemiological week of 2020, respectively. During 2020, the country reached the first peaks of new cases and deaths from COVID-19 
in the 30th epidemiological week, with absolute numbers of 319,653 cases and 7677 deaths, respectively. After a decline in these numbers, Brazil experienced a second wave of the disease with 333,028 new cases and 5233 deaths due to COVID-19 in the 51st epidemiological week of $2020^{11}$. Hence, our data collection took place between the first and second waves of cases.

The recruitment of participants took place through invitations sent by e-mails to university leaders and these were sent to linked students. In addition, institutional websites and social networks of the institutions were used to disclose the link to access the questionnaire. Individuals aged between 18 and 59 years, of both sexes and who were university students were included. Subjects submitted to bariatric surgery, pregnant women and lactating women were not included. Individuals who did not self-report race/skin color were excluded.

\section{Sampling and sample size}

To calculate the sample size of the primary study, 95\% confidence and $1 \%$ acceptable margin of error were adopted. The population size was considered 8449521 individuals, corresponding to the number of students enrolled in higher education institutions in Brazil in 2018, according to data from higher education statistics ${ }^{12}$ and an expected frequency of $10 \%$ of food addiction. Thus, 3456 university students were needed to compose the sample. Since there is important heterogeneity in the geographic distribution of this student population across the country, the sample was weighted by the number of university students in each of the macroregions of Brazil. Administratively, the country is divided into 27 Federative Units that make up its five macro-regions: North, Northeast, Midwest, Southeast and South ${ }^{13}$. Thus, $283(8.20 \%$ of the sample) individuals were needed in the North, 736 $(21.30 \%)$ in the Northeast, $317(9.20 \%)$ in the Midwest, 1536 (44.40\%) in the Southeast and 584 $(16.80 \%)$ in the South. These numbers were further weighted by the population of each Federative Unit.

\section{Demographic and lifestyle variables}

Data on age (in years), date of birth, sex, educational institution, Federative Unit, race/skin color (white [Caucasian], black [Afro-descendant], brown, yellow [Asian], indigenous) were collected.

\section{Economic class}

To determine the economic class, the Brazil Economic Classification Criterion was used. This instrument consists of questions about property ownership, the presence of monthly domestic employees and the number of bathrooms in the household. The education level of the head of the family and access to public services such as running water and paved street is also considered. A value is assigned to each answer and a sum of the scores is made for each individual, which can vary from 0 to 100 points, the higher the score, the higher the estimated average household income. Individuals are then classified into six economic classes: "A" (45-100 points), "B1" (38-44 points), "B2" (29-37 points), "C1" (23-28 points), "C2" (17-22 points), "D-E" (0-16 points) ${ }^{14}$.

\section{Diagnosis of COVID-19 and adherence to social distancing}

The medical diagnosis of COVID-19 was self-reported and collected through a direct question "Did you have a medical diagnosis of COVID-19?" with a dichotomous response (yes or no). Medical tests or certificates were not collected to confirm the information provided.

Adherence to social distancing measures was also self-reported and collected through the question "Did you follow the social distancing measures?", Participants could answer "I followed social distancing most of the time, only going to supermarkets and pharmacies", "I followed the social distancing, but I had to leave to work" or "I didn't follow the social distancing".

\section{Statistical analysis}

Before statistical analysis, the database was checked unlikely data. We removed individuals who answered the questionnaire in duplicate and those who entered unlikely values for open questions (age and date of birth).

In the descriptive analysis, data are presented as means and standard deviations for continuous variables and frequencies for categorical variables. Poisson's regression with robust adjustment of variance was used to identify the factors associated with the medical diagnosis of COVID-19 (dependent 
variable; " 0 " without diagnosis and " 1 " with diagnosis), in univariable analyses and in multivariable models including age, sex, race/skin color, economic class, region of the country and adherence to measures of social distancing as independent variables. The prevalence ratios (PR) adjusted in the model and the $95 \%$ confidence interval $(95 \% \mathrm{CI})$ are presented. For all analyses, a equal to $5 \%$ was adopted. All analyses were conducted with the statistical software R v.3.6.1 ( $R$ Foundation for Statistical Computing, Vienna, Austria).

\section{RESULTS}

In all, 6532 questionnaires were answered on the online platform. After the procedures for cleaning the database, checking data, and applying inclusion criteria, 548 questionnaires were excluded. Of this, 223 questionnaires were excluded because they were duplicated and 4 presented improbable data in open questions. Figure 1 shows the flowchart of the participants.
For this analysis, 5984 participants were included. With this number of participants included, it was possible to reach the planned weighted sample in all macro-regions of the country.

The mean age of the individuals was $24.1 \pm 6.4$ years, most including female participants $(n=4404$; $73.60 \%)$ and individuals from the Northeast $(n=2636$; $44.10 \%)$. Most participants declared themselves to be white $(n=2945 ; 49.20 \%)$ and were from economic classes B2 and C1, with 1800 (30.10\%) and 1237 $(20.70 \%)$ individuals, respectively. The characteristics of the sample are described in detail in Table 1 . In this sample, $425(7.1 \%)$ of the participants reported the diagnosis of COVID-19.

The univariable and multivariable analyses between socioeconomic variables and social distancing and the diagnosis of COVID-19 can be seen in Table 2. After adjustment in the multivariable analysis, the association between the medical diagnosis of COVID-19 and age in years (PR: $1.01 ; 95 \% \mathrm{CI}$ :

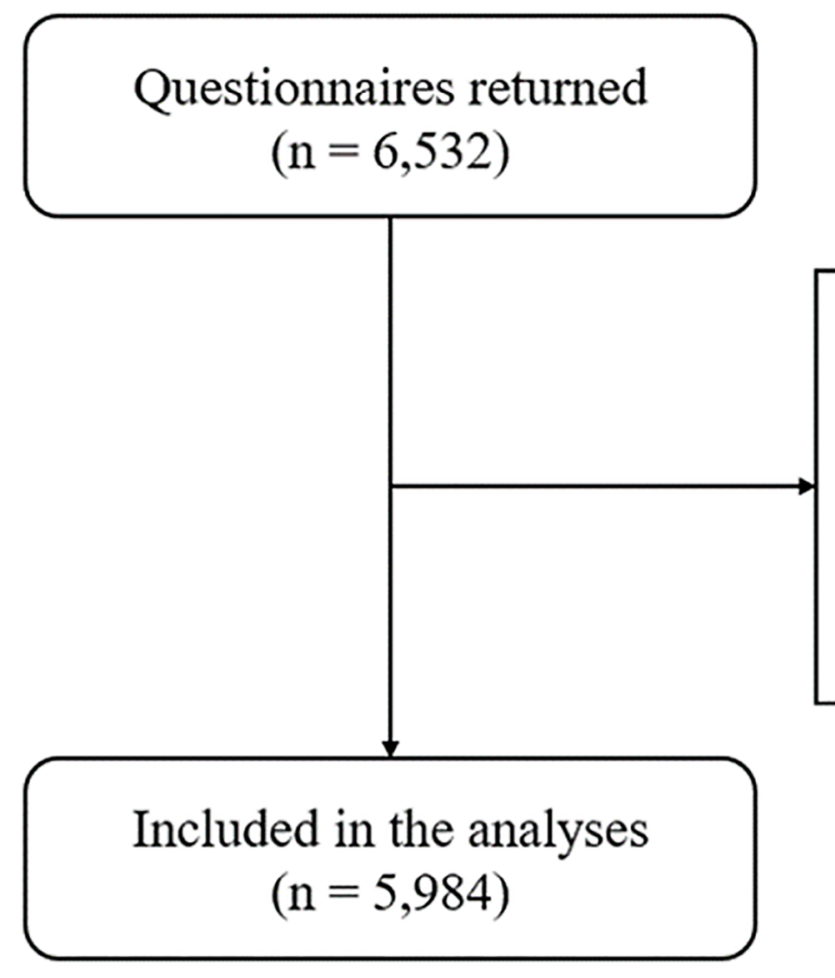

\section{Excluded $(\mathrm{n}=548)$}

Duplicate questionnaires $(\mathrm{n}=223)$

Did not meet the inclusion criteria $(n=127)$

Participant declined to participate $(\mathrm{n}=102)$

Did not report race/colour data $(n=92)$

Unlikely data $(\mathrm{n}=4)$

Figure 1. Flowchart of the participants

$1.00-1.02 ; p=0.04)$ was statistically significant. The association with non-white race/skin color, observed in the univariable analysis, did not remain after the statistical adjustment (PR: 1.19; 95\% CI:
$0.98-1.46 ; p=0.07)$, being the race/skin color "white" the reference. When the total adherence (i.e. leaving home only for going to the supermarket and pharmacy) was adopted as the reference, there were 
Table 1. Sample characteristics awccording to demographic social and econowmic variables

\begin{tabular}{|c|c|c|}
\hline \multirow[t]{2}{*}{ Variable } & \multicolumn{2}{|c|}{$\begin{array}{c}\text { Sample } \\
(n=5,984)\end{array}$} \\
\hline & $\mathrm{n}$ & $\%$ \\
\hline \multicolumn{3}{|l|}{ Sex } \\
\hline Female & 4,404 & 73.6 \\
\hline Male & 1,580 & 26.4 \\
\hline \multicolumn{3}{|l|}{ Region } \\
\hline North & 382 & 6.4 \\
\hline Northeast & 2,636 & 44.1 \\
\hline Midwest & 380 & 6.4 \\
\hline Southeast & 1,716 & 28.7 \\
\hline South & 870 & 14.4 \\
\hline \multicolumn{3}{|l|}{ Race/colour } \\
\hline White (Caucasian) & 2,945 & 49.2 \\
\hline Black (Afro-descendant) & 749 & 12.5 \\
\hline Brown & 2,185 & 36.5 \\
\hline Yellow (Asian) & 72 & 1.2 \\
\hline Indigenous & 33 & 0.6 \\
\hline \multicolumn{3}{|l|}{ Economic class } \\
\hline A & 822 & 13.7 \\
\hline B1 & 951 & 15.9 \\
\hline B2 & 1,800 & 30.1 \\
\hline $\mathrm{C} 1$ & 1,237 & 20.7 \\
\hline $\mathrm{C} 2$ & 840 & 14.0 \\
\hline$D-E$ & 334 & 5.6 \\
\hline \multicolumn{3}{|l|}{ Social distancing } \\
\hline $\begin{array}{l}\text { Adhered the social } \\
\text { distancing for most of } \\
\text { the time, performing only } \\
\text { visits to supermarkets and } \\
\text { pharmacies }\end{array}$ & 4,407 & 73.7 \\
\hline $\begin{array}{l}\text { Adhered the social } \\
\text { distancing, but had to } \\
\text { leave to work }\end{array}$ & 1,391 & 23.2 \\
\hline $\begin{array}{l}\text { Did not adhere to social } \\
\text { distancing }\end{array}$ & 186 & 3.1 \\
\hline
\end{tabular}

significant associations between the diagnosis of COVID-19 and partial adherence to social distancing (i.e. leaving home to work) (PR: $1.35 ; 95 \% \mathrm{CI}$ : $1.10-1.66 ; \mathrm{p}<0.01)$ and with non-adherence to social distancing (PR: 1.96 ; 95\% CI: $1.29-2.97$; $p<$ 0.01 ). No significant association was found between the diagnosis of COVID-19 and sex and economic class in the multivariable analysis.

\section{DISCUSSION}

To our knowledge, this is the first study that investigated the association between the diagnosis of COVID-19 and its relationship with the economic class, race/skin color, and measures of social distance in Brazilian university students. The medical diagnosis of COVID-19 was also associated with age, partial adherence and non-adherence to social distancing, even in the multivariable analysis. Still, it was not associated with economic class and race/skin color.

Economic inequality can play an important role in the impact of COVID-19 on Brazilian territory. A study developed by Demenech et al. ${ }^{15}$, found that the states with the highest concentration of income, analyzed by the Gini coefficient, were associated with the increase in incidence and mortality rates due to COVID-19. Although no association was found between the diagnosis of COVID-19 and the economic class of the participants in our study, there is evidence that for the most disadvantaged communities, which have the highest rates of underlying clinical risk factors such as chronic non-communicable diseases, COVID-19 is experienced as a syndemia - a synergistic pandemic that simultaneously interacts and worsens these diseases and the precarious social conditions that exist in this layer of society ${ }^{16}$.

It is worth considering that social distancing may not be practicable in some places, which may explain a greater non-adherence to distancing measures, since the severe impact of COVID-19, together with an unstable federal government, can make the country particularly susceptible to inequalities in outcomes ${ }^{17}$. In the North and Northeast Regions, these effects of pandemics can be even more pronounced, as they are less developed regions and with the most vulnerable populations ${ }^{17}$. People with less income are more likely to report circumstances that hinder the adoption of self-protection behaviors, such as the inability to telecommute, more likely to use public transport, which increases their exposure to the virus ${ }^{16,18}$.

Implementing the combined intervention of quarantining infected individuals and their families, leaving the workplace, and closing schools as soon as transmission in the community is detected can substantially reduce the number of SARSCoV-2 infections ${ }^{19}, 20$. As observed in our results, partial adherence and non-adherence to social distancing were associated with the diagnosis of 
Table 2. Univariable and multivariable prevalence ratios for the diagnosis of COVID-19 in Brazilian university students according to demographic, social and economic variables

\begin{tabular}{|c|c|c|c|c|c|c|}
\hline \multirow[t]{2}{*}{ Variables } & \multicolumn{3}{|c|}{ Univariable analysis } & \multicolumn{3}{|c|}{ Multivariable analysis ${ }^{a}$} \\
\hline & PR & $95 \%$ CI & $\mathbf{p}$ & PR & $95 \% \mathrm{CI}$ & $\mathbf{P}$ \\
\hline Age (in years) & 1.01 & $1.00-1.03$ & $<0.01$ & 1.01 & $1.00-1.02$ & 0.04 \\
\hline \multicolumn{7}{|l|}{ Sex } \\
\hline Female & 1.00 & - & - & 1.00 & - & - \\
\hline Male & 0.99 & $0.81-1.22$ & 0.98 & 0.91 & $0.73-1.12$ & 0.38 \\
\hline Region & & & $<0.01$ & & & $<0.01$ \\
\hline Northeast & 1.00 & - & - & 1.00 & - & - \\
\hline North & 1.96 & $1.50-2.56$ & $<0.01$ & 1.81 & $1.38-2.38$ & $<0.01$ \\
\hline Midwest & 0.72 & $0.47-1.10$ & 0.13 & 0.67 & $0.44-1.04$ & 0.07 \\
\hline Southeast & 0.67 & $0.53-0.85$ & $<0.01$ & 0.67 & $0.53-0.85$ & $<0.01$ \\
\hline South & 0.56 & $0.40-0.78$ & $<0.01$ & 0.57 & $0.40-0.80$ & $<0.01$ \\
\hline \multicolumn{7}{|l|}{ Race/colour } \\
\hline White & 1.00 & - & - & 1.00 & - & - \\
\hline Non-whiteb & 1.43 & $1.19-1.73$ & $<0.01$ & 1.19 & $0.98-1.46$ & 0,07 \\
\hline Economic class & & & 0.68 & & & 0.49 \\
\hline$A$ & 1.00 & - & - & 1.00 & - & - \\
\hline B1 & 0.94 & $0.66-1.33$ & 0.73 & 0.89 & $0.63-1.26$ & 0.52 \\
\hline B2 & 1.03 & $0.76-1.40$ & 0.82 & 0.94 & $0.70-1.28$ & 0.73 \\
\hline $\mathrm{C} 1$ & 1.19 & $0.87-1.64$ & 0.25 & 1.01 & $0.74-1.39$ & 0.91 \\
\hline $\mathrm{C} 2$ & 0.99 & $0.69-1.42$ & 0.98 & 0.79 & $0.55-1.13$ & 0.20 \\
\hline$D-E$ & 1.01 & $0.63-1.61$ & 0.96 & 0.72 & $0.45-1.16$ & 0.18 \\
\hline Social distancing & & & $<0.01$ & & & $<0.01$ \\
\hline $\begin{array}{l}\text { Adhered the social } \\
\text { distancing for } \\
\text { most of the time, } \\
\text { performing only visits } \\
\text { to supermarkets and } \\
\text { pharmacies }\end{array}$ & 1.00 & - & - & 1.00 & - & - \\
\hline $\begin{array}{l}\text { Adhered to social } \\
\text { distancing, but had to } \\
\text { leave to work }\end{array}$ & 1.37 & $1.12-1.68$ & $<0.01$ & 1.35 & $1.10-1.66$ & $<0.01$ \\
\hline $\begin{array}{l}\text { Did not adhere to } \\
\text { social distancing }\end{array}$ & 1.85 & $1.23-2.79$ & $<0.01$ & 1.96 & $1.29-2.97$ & $<0.01$ \\
\hline
\end{tabular}

PR: Prevalence ratio by Poisson's regression with robust adjustment of variance; $95 \% \mathrm{Cl}$ : $95 \%$ confidence interval; aPrevalence ratios for the diagnosis of COVID-19 in multivariable models including age, sex, region of Brazil, race/colour, economic class and adherence to social distancing as independent variables. ${ }^{b}$ Non-white is the combination of individuals who self-declared black (Afro-descendant), brown, yellow (Asian) and indigenous.

COVID-19. In an online survey, conducted in Brazil, it was observed that adherence scores for specific measures (washing hands, wearing a mask and social distancing) were all significantly lower in the younger age group (18-25 years) when compared to individuals in the age groups $26-65$ years and upper 65 years $^{21}$.
In addition to economic diversity, and although Brazil is a country with great ethnic diversity, however, it was not possible to observe in the present study an association between race/skin color and infection by COVID-19. On the other hand, it is worth mentioning that there is robust evidence involving the association between race/skin color/ethnicity and susceptibility and mortality in SARS-CoV2 infection. In the study by 
Hallal et al. ${ }^{22}$, conducted in Brazil between the 20th and 24th epidemiological weeks of 2020, which assessed the prevalence of SARS-CoV-2 antibodies through the results of two successive serological home surveys, it was observed that, in terms of ethnicity, the second-highest prevalence $(2.4 \%$ [95\% CI: $2.0-2.8 \%$ ] in the first survey and $3.6 \%$ [95\% CI: 3.2-4.0\%] in the second) was found in the participants self-declared brown (mixed ethnicity). Among hospitalized patients, brown and black Brazilians with COVID-19 had significantly higher mortality rates than white Brazilians ${ }^{17}$.

Social and economic variables are often related to health outcomes, and the same seems to be true during the COVID-19 pandemic. In this sense, higher infection rates by the new coronavirus have been reported in blacks and mixed ethnicity than in whites ${ }^{23}$, and low education was associated with non-adherence to COVID-19 prevention measures ${ }^{24}$. Interestingly, this relationship was not observed in our study, since the participants were university students, education, in this case, was possibly able to attenuate the relationship between SARS-CoV-2 infection and race/skin color and economic class.

The present study has some limitations, initially, as it is an online survey, as the results of our study are based on self-reports, there is the impossibility of verifying whether these responses corresponded to the behavior of the participants. In addition, the medical diagnosis of COVID-19, reported by the participants, should be interpreted with caution, given the wellknown phenomenon of diagnostic bias, which means that people with symptoms may have chosen to seek health services and to perform the specific test more often than people without symptoms.

In conclusion, the diagnosis of COVID-19 was associated with age, non-adherence, and partial adherence to social distancing measures in Brazilian university students. Given the important role of social determinants in health, it is highlighted that our study serves as a generator of the hypothesis that education may have been able to attenuate the relationship between race/skin color, economic class, and COVID-19 in Brazilian university students, raising the need to conduct studies designed to advance the understanding of these relationships.

\section{REFERENCES}

1.WHO. Declaration of Public Health Emergency of International Concern, https://www.who.int/ emergencies/diseases/novel-coronavirus-2019/eventsas-they-happen; 2020 [Accessed January 2021].

2.Teich VD, Klajner S, Almeida FAS, Dantas ACB, Laselva CR, Torritesi, MG, et al. Epidemiologic and clinical features of patients with COVID-19 in Brazil. Einstein 2020;18:1-7.

3. Mohapatra RK, Pintilie L, Kandi V, Sarangi, AK, Das D, Sahu $R$, et al. The recent challenges of highly contagious COVID-19, causing respiratory infections: Symptoms, diagnosis, transmission, possible vaccines, animal models, and immunotherapy. Chem Biol Drug Des 2020;96:1187-1208.

4. Rothan HA, Byrareddy SN. The epidemiology and pathogenesis of coronavirus disease (COVID-19) outbreak. J Autoimmun 2020;109:102433.

5. Marson FAL, Ortega MM. COVID-19 in Brazil. Pulmonology $2020 ; 26: 241-244$.

6.Wilder-Smith A, Freedman DO. Isolation, quarantine, social distancing and community containment: pivotal role for old-style public health measures in the novel coronavirus (2019-nCoV) outbreak. J Travel Med 2020;27:taaa020.

7.Bong $\mathrm{CL}$, Brasher $\mathrm{C}$, Chikumba E, McDougall R, MellinOlsen J, Enright A. The COVID-19 Pandemic: Effects on Low- and Middle-Income Countries. Anesth Analg 2020;131:86-92.

8. Nicola M, Alsafi Z, Sohrabi C, Kerwan A, Al-Jabir A, Iosifidis $C$, et al. The Socio-Economic Implications of the Coronavirus and COVID-19 Pandemic: A Review. Int J Surg 2020;78:185-193.

9.Amaral-Prado HM, Borghi F, Mello TMVF, Grassi-Kassisse DM. The impact of confinement in the psychosocial behaviour due COVID-19 among members of a Brazilian university. Int J Soc Psychiatry Published Online First: 8 November 2020. doi: 10.1177/0020764020971318

10.Carlson ER. COVID-19 and Educational Engagement. J Oral Maxillofac Surg 2020;78:1049-1051.

11. Brasil. Ministério da Saúde. Painel de casos de doença pelo coronavírus 2019 (COVID-19) no Brasil, 2020 https://covid.saude.gov.br [Accessed January 2021].

12.Instituto Nacional de Pesquisas Educacionais Anísio Teixeira. Sinopse Estatística da Educação Superior 2018. Brasília: INEP; 2019.

13.IBGE - Instituto Brasileiro de Geografia e Estatística. Censo Demográfico 2010. Resultados gerais da amostra. Rio de Janeiro: IBGE; 2012.

14.Associação Brasileira de Empresas de Pesquisas. Critérios de classificação econômica Brasil. São Paulo: ABEP; 2020.

15.Demenech LM, Dumith SC, Vieira MECD, Neiva-Silva, L. Income inequality and risk of infection and death by COVID-19 in Brazil. Rev Bras Epidemiol Published Online First: 05 October 2020. doi: 10.1590/1980-549720200095

16.Bambra C, Riordan R, Ford J, Matthews F. The COVID-19 pandemic and health inequalities. $J$ Epidemiol Community Health 2020;74:964-968. 
17.Souza CDF, Machado MF, Carmo RF. Human development, social vulnerability and COVID-19 in Brazil: a study of the social determinants of health. Infect Dis Poverty 2020;9:124.

18.Papageorge NW, Zahn M, Belot M, Broek-Altenburg EV, Choi S, Jamison JC, et al. Socio-demographic factors associated with self-protecting behavior during the Covid-19 pandemic. J Popul Econ Published Online First: 14 January 2021. doi: 10.1007/s00148-020-00818-x

19. Koo JR, Cook AR, Park M, Sun Y, Sun H, Lim JT, et al. Interventions to mitigate early spread of SARS-CoV-2 in Singapore: a modelling study. Lancet Infect Dis 2020;20:678-688.

20.Lewnard JA, Lo NC. Scientific and ethical basis for socialdistancing interventions against COVID-19. Lancet Infect Dis 2020;20:631-633.

21.Villela EFM, López, RVM, Sato APS, Oliveira FM, Waldman EA, Van den Bergh R, et al. COVID-19 outbreak in
Brazil: adherence to national preventive measures and impact on people's lives, an online survey. BMC Public Health 2020;21:152.

22. Hallal PC, Hartwig FP, Horta BL, Silveira MF, Struchiner CJ, Vidaletti, LP, et al. SARS-CoV-2 antibody prevalence in Brazil: results from two successive nationwide serological household surveys. Lancet Glob Health 2020;8:1390-1398.

23. Mathur R, Rentsch CT, Morton CE, Hulme WJ, Schultze A, MacKenna B et al. Ethnic differences in SARS-CoV-2 infection and COVID-19-related hospitalisation, intensive care unit admission, and death in 17 million adults in England: an observational cohort study using the OpenSAFELY platform. Lancet 2021;397(10286):1711-1724.

24.Ditekemena JD, Nkamba DM, Muhindo HM, Siewe JNF, Luhata C, Van der Bergh $\mathrm{R}$ et al. Factors associated with adherence to COVID-19 prevention measures in the Democratic Republic of the Congo (DRC): results of an online survey. BMJ Open 2021;11:e043356. 


\section{Acknowledgments}

The authors would like to thank by the Coordenação de Aperfeiçoamento de Pessoal de Nível Superior - Brazil (CAPES) research fellowships.

\section{Competing interests}

None declared.

\section{Funding}

A.E.S.J. is supported by the Coordenação de Aperfeiçoamento de Pessoal de Nível Superior - Brazil (CAPES) research fellowships (grant number: 88887.480702/2020-00). M.L.M. is supported by the Coordenação de Aperfeiçoamento de Pessoal de Nível Superior - Brazil (CAPES) research fellowships (grant number: 23065.005919/2021-75). D.R.S.P. is supported by the Coordenação de Aperfeiçoamento de Pessoal de Nível Superior - Brazil (CAPES) research fellowships (grant number: 23065.005919/2021-75). I.R.O.M.P. is supported by the Coordenação de Aperfeiçoamento de Pessoal de Nível Superior - Brazil (CAPES) research fellowships (grant number: 88887.465281/2019-00).

\section{Corresponding author:}

Nassib Bezerra Bueno

nassib.bueno@fanut.ufal.br

Editor:

Prof. Dr Felipe Villela Gomes

Received: may 17, 2021

Approved: jul 06, 2021 